\title{
Carcinoma of the Conjunctiva Pathologic Regional Lymph Nodes TNM Finding v7
}

National Cancer Institute

\section{Source}

National Cancer Institute. Carcinoma of the Conjunctiva Pathologic Regional Lymph

Nodes TNM Finding v7. NCI Thesaurus. Code C88602.

A pathologic finding about one or more characteristics of carcinoma of the conjunctiva, following the rules of the TNM AJCC V7 classification system as they pertain to staging of regional lymph nodes. 